\title{
Homeward bound FDI: Are migrants a bridge over troubled finance?
}

Article in Economic Modelling · June 2016

Impact Factor: 0.7 · DOI: 10.1016/j.econmod.2016.05.021

READS

11

3 authors, including:

Joan Martín-Montaner

Universitat Jaume I

22 PUBLICATIONS 115 CITATIONS

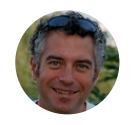

Jordi Paniagua

Catholic University of Valencia "San Vicente...

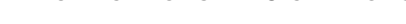

26 PUBLICATIONS 53 CITATIONS

SEE PROFILE

SEE PROFILE 


\title{
Homeward bound FDI: Are migrants a bridge over troubled finance?*
}

\author{
Ana Cuadros ${ }^{1,2}$, Joan Martín-Montaner ${ }^{1,2}$, and Jordi Paniagua ${ }^{\ddagger 3,2}$ \\ ${ }^{1}$ Universitat Jaume I \\ ${ }^{2}$ Instituto de Economía Internacional \\ ${ }^{3}$ Catholic University of Valencia San Vicente Mártir
}

6th June 2016

\begin{abstract}
Migrants can lower cross-border investment barriers, help investors by providing information about their homeland and reduce transaction costs by sharing expertise on regulations, customs and procedures. In addition to generating these well-known networking effects, migrants can also provide valuable information about local finance, thereby easing the credit constraints foreign investors faced during the 2007 financial crisis. This paper sheds new light on the underlying mechanisms through which migration may affect foreign investment in the migrant's homeland by distinguishing between the effects on FDI's intensive and extensive margins. Gravity estimates for 140 countries for the period 2003-2012 suggest that migrants exert a positive effect on bilateral FDI. However, financial constraints moderate this effect, primarily through the extensive margin. Additionally, quantile regression reveals that the interaction between migration and credit constraints is significant only for the lower levels of FDI. Our findings contribute to a better understanding of the interplay among migration, financial constraints and FDI.
\end{abstract}

Keywords: FDI, migration, intensive and extensive margins, financial constraints, gravity equation

JEL Classification: F22, F23, F16

*This is an Author's Accepted Original Manuscript of an article published in Economic Modelling [5 June 2016] [copyright Elsevier], available online at: http://dx.doi.org/10.1016/j.econmod. 2016.05 .021$.

†Please cite this article as: Cuadros, A., Martín-Montaner, J. \& Paniagua, J. (2016) Homeward bound FDI: Are migrants a bridge over troubled finance?, Economic Modelling, DOI: 10.1016/j.econmod.2016.05.021

$\ddagger$ Corresponding author jordi.paniagua@ucv.es 


\section{Introduction}

"On 2015, July 6, Chinese Premier Li Keqiang invited more than 450 Chinese business leaders from around the world to Beijing. He asked them to help support China's economy, saying that overseas Chinese are the key to the nation's future as they form a bridge between China and the outside world" (The Nation, Thailand's Independent Newspaper, 2015, 20th July).

It is not uncommon that policymakers support their diaspora as ambassadors for prospective foreign investors. This evidence comes as an acknowledgement that developing countries may benefit from entrepreneurial migrants who establish businesses abroad. For instance, the first foreign company to establish in modern China was Thailand CP Group, founded by Chinese emigrants to Thailand. All the Chinese diaspora in South East Asia (often labelled as the Bamboo Network) illustrates how migrants have shaped foreign direct investment (FDI) in their home countries, but it is not the only case. Morocco has implemented a plan to channel migrants' money transfers through the formal banking system, while Turkey has encouraged migrants to invest back home (Eckstein, 2013). These policies highlight the governments' faith in the existence of multiple effects of migrants on their native economies.

This paper focuses on the role of migrants in promoting FDI. Since Gould (1994) published his seminal work, extensive research has documented a positive association between ethnic networks and international trade. Most of this literature focuses on the so-called network channel. In other words, the fact that migrants share useful knowledge about their home countries helps exporters to reduce transaction costs and therefore enhances bilateral trade. In contrast, there has been little research on the link between migrants and foreign direct investment (FDI).

Despite this lack of research, however, FDI activities face larger information asym-

metries than international trade transactions, which would imply that networks play 
a more important role in bilateral FDI than in trade (see Tong, 2005; Aubry et al., 2014). Javorcik et al. (2011) emphasized that FDI implies a long-term investment and therefore requires a wider variety of information about the market, legal framework and business structure in the host country. FDI's long-term nature explains why some authors argue that FDI flows are more sensitive to information frictions than investment portfolio equity and debt securities are (Daude and Fratzscher, 2008). Related to this issue, several authors have argued that since FDI decisions involve higher fixed costs than exports do, financial constraints are likely to constitute a key issue in FDI (Alfaro et al., 2004; Buch et al., 2014). In fact, since the sudden halt in FDI flows in the aftermath of the Great Recession, research focusing on the effect of financial frictions in multinational investment has emerged. Moreover, casual evidence suggests that financial crises also affect the way information and resources are spread through informal networks ${ }^{1}$.

The contribution of this paper is twofold. First, we consider migrants born in county $j$ but living in country $i$ as a factor determining FDI flows from country $i$ to country $j$. Particularly, we consider that migrants reduce the marginal cost related to the information transfer between headquarters and affiliates. Capital is just one of many factors transferred from the headquarters to an affiliate in a foreign location. We build on the idea of headquarter services (Helpman, 1984) to develop a model in which the migrant's information reduces the marginal cost of transferring headquarter services (e.g., management, financial or marketing services). In essence, information on foreign tastes, demand preferences, management style and the foreign banking system reduces the headquarter's risk when undertaking foreign endeavours. Second, this paper provides new insights into the FDI-migration link, stressing the

\footnotetext{
${ }^{1}$ According to Chen (2004), before the 1997 Asian financial crises, business relationships in the Bamboo Network were more frequently based on trust and family ties than on contracts. However, after the crises, network ties seem to weaken their effect in favour of more conventional channels.
} 
role of the aforementioned financial frictions. More specifically, we examine the moderating role of banking crises in the FDI-migration link. If part of the information provided by migrants relates to finance (e.g., alternative sources of credit and foreign banks), financial constraints arising from systemic banking crises should interfere in the otherwise positive effect of migrants.

We develop a stylized model, in the spirit of Melitz (2003), Helpman et al. (2008) and Manova (2013). The model offers several testable empirical predictions consistent with our previous argument. Our empirical strategy is to estimate an extended gravity equation. We include the number of migrants and their interaction with a systemic financial crisis (i.e., extreme financial friction that shocks an economy) as additional explanatory variables of FDI. We draw upon a database covering bilateral greenfield investments from 2003 to 2012. By doing so, we disentangle the effects of the explanatory variables on the volume and number of FDI projects (intensive and extensive margins, respectively).

Our results provide evidence that migrants from country $j$ (FDI host country) have a positive and significant effect on bilateral FDI directed towards their homeland (for both intensive and extensive margins). Our estimates also indicate the existence of two offsetting effects of financial constraints on the effects on migrants. On the one hand, financial frictions in the source country of investment increase the positive effect of migrants. This would seem to suggest that when traditional channels fail (as is the case in a banking crisis) migrants might provide information about alternative financial possibilities in their homeland. On the other hand, this effect is lower when banking crises occur in the host country of investment since the information that migrants transmit about their homeland is likely to become distorted by the financial collapse and its aftermath (e.g., changes in the financial sector due to mergers, bankruptcies or new policies). 
Moreover, information provided by migrants is likely to be more relevant when headquarter services are more important, as it is the case with small FDI projects, especially in situations of financial distress. Hence, we also perform quantile regression analysis to examine whether the incidence of migration depends on FDI levels. Results obtained confirm this hypothesis.

The remainder of the paper has the following structure. Section 2 briefly summarizes the existing literature. Section 3 presents the theoretical framework. Section 4 explains the data and empirical methodology. Section 5 discusses results. Finally, section 6 offers conclusions.

\section{Background}

New approaches in the literature stress that uncertainty and imperfect information impose barriers to trade and investment from MNEs (see Buch et al., 2006; Aubry et al., 2014). Based on the theory of networks, these approaches suggest that both emigrants and immigrants have positive and significant effects on bilateral trade and FDI flows. But whereas scholars have extensively analysed the relationship between migration and trade, the FDI-migration link has received less attention until recently.

FDI and migration may interact in several ways. For example by acting as an information-revealing network, migrants may stimulate foreign investment. This could happen, for example, when people living abroad demand products or services from their home country and companies try to satisfy these needs by investing abroad (Javorcik et al., 2011). Thus, migrants help companies to identify business opportunities, local tastes and foreign preferences. In this sense, migrants may help to identify new economic opportunities in their homeland through personal ties between expat- 
riates and business communities. In fact, cultural factors seem particularly likely to influence FDI because FDI involves not only a transfer of foreign capital, but also a lasting interest in the acquired company (see Bandelj, 2002). In other words, foreign employees may act as knowledge brokers who transfer knowledge from where it is known to where it is unknown (Paniagua and Sapena, 2013; Bergstrand et al., 2008).

Ethnic networks may also help to enforce contracts across national boundaries (see Javorcik et al., 2011; Tong, 2005). As noted by Docquier and Lodigiani (2010), ethnic networks create (or substitute for) trust in a weak international legal environment. Trust matters, especially in developing and emerging economies, where the rule of law is weak. Thus, networks provide community enforcement of contracts.

Migrants may also act as business developers. Such migrants are individuals of a certain ethnicity who possess specific knowledge about how to conduct business in countries associated with that ethnicity (see Foley and Kerr, 2013). The entrepreneur's characteristics reside in ethnic resources built on trust and friendship arising from social networking relationships with other entrepreneurs from the same ethnic background (Rueda-Armengot and Peris-Ortiz, 2012) ${ }^{2}$. These resources may materialize through intangible outcomes (e.g., information, orientation and advice) and tangible outcomes (e.g., financing), the latter constituting the focus of our analysis.

Individual case studies have identified evidence supporting these network effects. The United States and China are probably the most extensively analysed case studies $^{3}$. Our study provides additional insights into the FDI-migration link because, as far as we know, only a handful of multi-country studies exist. Docquier and Lodigiani $\underline{(2010)}$ analysed a sample of 150 countries between 1980 and 2000, and reported evid-

\footnotetext{
${ }^{2}$ See also the work by Saxenian (2002) on American transnational entrepreneurs.

${ }^{3}$ See Javorcik et al. (2011); Kugler and Rapoport (2007); Bhattacharya and Groznik (2008), and Foad (2012) for analysis of US. Tong (2005) and Gao (2003) focused on the Chinese case. Other countries' experiences have also been analysed: Buch et al. (2006) (Germany), Gheasi et al. (2013) (UK), and Murat and Pistoresi (2009) (Italy).
} 
ence that supports the existence of business network externalities mainly associated with the skill diaspora. By using the stock of FDI-funded capital per worker as the dependent variable, these authors found that a highly educated diaspora stimulates physical capital accumulation. This effect is stronger for large countries. Therefore, even if brain drain depresses the average schooling level, FDI is likely to rise. Flisi and Murat (2011) stress that migrant networks develop transnational networks whereby information on opportunities concerning the origin and destination economies circulates more easily and efficiently. Aubry et al. (2014) covered a sample of 203 countries for the period 2001-2006. Aubry et al.'s study was the first to investigate the relationship between trade, migration and FDI in a unified framework. The study reported that migration helps to form business links that lead to FDI project deployment in a particular location. If migrants become part of a business community, a network can emerge whereby migrants liaise with potential investors and partners seeking to establish a production facility in the migrants' country of origin $^{4}$. In other words, migrants transmit information not only about distribution (useful for both exports and FDI) but also about setting up a production facility (useful for MNEs when locating their subsidiaries). Aubry et al.'s findings indicate that the ratio of FDI to exports is higher when there is a higher stock of migrants in the exporting country, if that country is also the home country for multinational investment. Thus, although migration positively affects both trade and FDI (in terms of both the extensive and intensive margins), the effect on FDI is greater ${ }^{5}$.

The above studies have reported an FDI-migration link as evidence supporting

\footnotetext{
${ }^{4}$ According to these authors, while this channel seems to apply mainly to skilled migrants, unskilled migrants may also contribute, through other channels, to relaxing information constraints on FDI: participation in the destination country's labour force reveals information about the worker characteristics in the home country, thereby reducing uncertainty about FDI. Hence, both skilled and unskilled migration can convey information to facilitate FDI inflow to the home country.

${ }^{5}$ Ivlevs and De Mello (2010) also analysed trade, FDI and migration in a unified framework from migration-sending countries' perspective. Results for a sample of 103 countries indicate that if exports are low-skill intensive, emigration of highly skilled labour leads to positive FDI.
} 
positive network externalities based on the information advantage of migrants and strong family and cultural ties to their homeland. However, the channel through which this information affects investment decisions remains mostly unexplored. In the FDI literature, headquarter services constitute the usual mechanism for the intrafirm transfer of management, marketing and financial information needed for foreign production. Initially, these headquarter services were basically understood as blueprints developed by the headquarters in the source country (Helpman, 1984). Today, headquarter services are the focus of a burgeoning strand of research because they explain how firms may absorb foreign costs and engage in FDI (Antràs and Helpman 2004).

A key issue is the firm's decision regarding where to locate the headquarter services. Davies (2005) argued that firms have incentives to spread headquarter services across countries to benefit from the imperfect substitution of labour from different countries. However, empirical research has shown that advantages for firms come from the separation of headquarter services and production activities. Thus, Davis and Henderson (2008) concluded that headquarter services tend to agglomerate in certain locations. This agglomeration allows firms to use the abundant human capital in those locations. In addition, agglomeration itself generates information spillovers among firms ${ }^{6}$. This decision, however, is costly in terms of communication and coordination costs (Henderson and Ono, 2008). Empirical evidence fails to provide a conclusive answer to the question of how to solve this trade-off. Whereas StraussKahn and Vives (2009) showed that firms are increasingly locating their headquarters in metropolitan areas with good business services, Cristea (2015) found that low communication costs mean that firms prefer to locate headquarter services in countries

\footnotetext{
${ }^{6}$ Lovely et al (2005), for instance, found that headquarter services for exporter firms tend to be more agglomerated than other firms because their information requirements are more difficult to find.
} 
with an abundance of low-skilled labour rather that export to these countries.

The foreign subsidiary usually pays a lower price than domestic firms for some business activities. Financial or marketing services profit from economies of scale when centralized at the firm's headquarters. For example, headquarter services allow the subsidiary to reinvest in the foreign market at a lower cost (Paniagua, 2015). However, the transfers of these services also entail transaction costs related to communication costs between headquarters and the affiliate. Evidence suggests that migrants networks are heavily involved in activities related to headquarters services like wholesaling, financing, sourcing, and transport (Weidenbaum and Hughes, 1996). Therefore, migrants living in the countries where headquarter services are located could mitigate the transaction costs of transferring these services, specifically finance services.

Rajan and Zingales (1998) reported that countries' financial development is relevant for financially constrained firms. Developed financial markets provide firms with access to the capital they need to invest in projects they might otherwise have to forego (Di Giovanni, 2005). Conversely, underdeveloped financial markets may constrain potential entrepreneurs (Alfaro et al., 2004). As highlighted by Héricourt and Poncet (2009, p.2), efficient investment "only results when businesses do not face credit constraints which are unrelated to their own performance". These authors reported that cross-border relationships between Chinese and foreign firms help private domestic firms to bypass the financial and legal obstacles they face at home. Thus, firms may need external financing to face the costs of entering foreign markets and expanding the business (Buch et al., 2014).

Yet financial constraints matter for certain firms only. Kroszner et al. (2007) reported two important findings regarding this point. First, during a banking crisis, value added contracts in those sectors that depend more on external financing. 
Second, reduction in value added is greater in countries whose financial markets are more evolved. Buch et al. (2014) reported similar results. Financial constraints have a greater effect on larger and/or more productive firms that are more likely to engage in FDI decisions.

We believe that credit constraints following the 2007 financial crisis constitute a relevant context for our analysis. As stated by Campello et al. (2010), the systemic financial crisis that began in 2007 has forced financially constrained firms to drop investment projects,whereas unconstrained firms have been able to continue with such projects. Similarly, Buch et al. (2014) reported that after the 2007 crisis, an increasing number of German firms have cited credit constraints as an impediment to expansion into foreign countries. Prior to the crisis, Alba et al. (2007) studied Japanese FDI in the U.S., finding that multiple rating downgrades of Japanese banks

significantly affected the rate of FDI in firms whose main financial sources were these downgraded banks. Gil Pareja et al. (2013) showed that credit constraints derived from systemic financial crises primarily affect FDI's extensive margin.

Therefore, because of the credit shortages following the 2007 financial crisis, we examine the role of migrants as a source of information about alternative financing options capable of offsetting the impact of credit constraints. Moreover, because these constraints may elevate the threshold for the required investment, firm heterogeneity matters. Thus, we examine whether the effectiveness of this new migrant-FDI mechanism varies depending on the FDI project's size.

\section{Theoretical framework}

In this section, we derive an estimable equation with predictions on the joint effect of migration and financial constraints on FDI. The model closely follows standard 
trade and FDI setups like those described by Melitz (2003), Helpman et al. (2008), Manova (2013), and Crinò and Ogliari (2015).

\section{The setup}

We start with a world of $J$ countries, represented by $i, j=1, \ldots, J$. As is common practice with FDI gravity models (e.g., Kleinert and Toubal, 2010), the initial setup starts with the assumption of a Cobb-Douglas utility function for variety-loving consumers in the host country,

$$
U_{j}=X_{A j}^{\mu} X_{B j}^{1-\mu}
$$

for a two sector economy with goods $\mathrm{A}$ and $\mathrm{B}$, where $\mu$ is a sector-wide parameter which describes the intensity of consumption of each good $(0<\mu<1)$. One of the sectors (e.g., A) is a non-trade sector, whereas sector B is open to foreign entry. The aggregate consumption of a good in the traded sector (we drop the subscript B for simplicity $\left.X_{j} \equiv X_{B j}\right)$ is a CES sub-utility function,

$$
X_{j}=\left[\int x_{k j}{ }^{\alpha} d k\right]^{1 / \alpha}
$$

where the host country $j$ 's consumption of good $B$ produced by firm $k$ from home country $i$ is denoted by $x_{k i j}$. The constant elasticity of substitution is $\sigma \equiv(1-\alpha)^{-1}>$ 1 and is equal for any product pair.

Maximization of (1) yields the following expression for the demand of the firm:

$$
x_{j}=\frac{p_{j}^{-\sigma}(1-\mu) Y_{j}}{P_{j}^{1-\sigma}},
$$

where $p_{j}$ are the transfer prices for each good's price and $P_{j}$ is the price index in 
country $j$, which is assumed to be a CES function,

$$
P_{j}=\left[\int_{k} p_{k i j}{ }^{1-\sigma} d k\right]^{1 /(1-\sigma)} .
$$

\section{Foreign production}

We assume that heterogeneous productivity splits the market between domestic, exporting and investing firms (Helpman et al., 2004; Melitz, 2003). Country $i$ has $N_{i}$ active monopolistic firms. Firms may attack the market by producing at home and exporting or producing the goods in country $j$. The firm uses $f_{i}$ units of an input bundle at a specific nationwide unit $\operatorname{cost}$ of $c_{i}$. To enter the industry, exporters pay a sunk cost of

$$
f_{i j}^{E x}=c_{i} f_{i j}
$$

Foreign production requires headquarter services, which increase the plant's technological, organizational and financial capabilities (Antràs and Helpman, 2004). Firms tailor their products with services like R\&D, innovation and marketing. Therefore, they capture the knowledge of the headquarters of country $j$ - its tastes in products (demand) as well as labour and capital regulation and management (production). Headquarter services are produced with labour at home. Headquarter services also affect the quality of the goods produced. The basic setup, therefore, is consistent with research by Crinò and Ogliari (2015) on export quality.

The plant uses these headquarter blueprints and combines capital and labour for production. Headquarter services, however, entail additional fixed costs:

$$
f_{i j}^{H Q}=c_{i} h_{i j}^{\gamma}
$$

where $h>1$ are the blueprints or units of HQ services, and $\gamma>0$ is the elasticity of 
the fixed cost to headquarter services (HQ). A foreign investor pays both sunk costs to enter the market:

$$
f^{F D I} \equiv f_{j}^{H Q}+f_{i j}^{E x}
$$

Upon entry, the firm discovers its productivity $1 / a$, where $a$ is the number of units of headquarter services per input bundle used by the firm to produce one unit of output. We follow the standard assumption that the distribution of $a$ across firms is a continuous Pareto c.d.f. $G(a)$ with $\left[a_{i j}^{*}, a_{L}\right]$, where $0<a_{L}<a_{i j}^{*}$. The density of $G(a)$ is denoted by $g(a)$, and the distribution is the same across countries.

To produce a good in destination $j$, a firm in country $i$ incurs a marginal cost,

$$
M C_{i j}(a)=\omega_{i j}\left(h_{i j} M_{j i}^{-\rho}\right)^{\delta}, \omega_{i j}(a) \equiv \tau_{i j} c_{i} a, \quad \delta \in(0,1)
$$

where $\tau_{i j}>1$ is an iceberg-type cost paid to transfer headquarter services between countries $i$ and $j, \delta$ is the elasticity of the marginal cost to headquarter services and $\omega_{k i j}(a)$ measures the marginal cost per blueprint. $M_{j i}>1$ is a measure of migrant information flows between countries and $\rho \in(0,1)$ is the fraction of migrant information that affects headquarter service provision. Therefore, $\rho \delta$ is the elasticity of the marginal cost to migration.

Migrants increase the information flow between countries. Migrants living in country $i$ but born in country $j$ increase the knowledge about tastes and reduce management costs. In sectors where headquarter services are irrelevant to the marginal cost of production $(\delta=0)$ or where migrants have no effect on alleviating the marginal costs of headquarter services $(\rho=0)$, however, the effect of migration is neutral. Intuitively, we can think of these as complex sectors with a high number of headquarter services. For firms in these sectors, the cost of additional services is 
lower than for firms producing simple products requiring only a few services from the parent firm. It is plausible that the effect of migration may be lower for complex products than for simple products.

\section{The firm problem}

The firm chooses $p_{i j}$ and $h_{i j}$ to maximize its profits in destination $j$ according to the following equation:

$$
\max _{p, h}\left(\left(p_{i j}-M C_{i j}(a)\right) x_{i j}-f^{F D I}\right)
$$

Hence, the optimal price, headquarter services and affiliate sales are given by:

$$
\begin{gathered}
p_{i j}^{o}=\frac{\omega_{i j}(a) h_{i j}^{\delta}}{M_{j i}^{\delta \rho} \alpha} \\
h_{i j}^{o}=\left[\left(\frac{\omega_{k i j}(a)}{M_{j i}^{\delta \rho} \alpha P_{j}}\right)^{1-\sigma} \frac{(1-\mu)(\tilde{\gamma}-\gamma) Y_{j}}{\sigma \gamma c_{i}}\right]^{1 / \tilde{\gamma}} \\
A S_{i j}^{o}=p_{i j} \cdot x_{i j}=\frac{\sigma \gamma c_{k i}}{(\tilde{\gamma}-\gamma)}\left[\left(\frac{\omega_{i j}(a)}{M_{j i}^{\delta \rho} \alpha P_{j}}\right)^{1-\sigma} \frac{(1-\mu)(\tilde{\gamma}-\gamma) Y_{j}}{\sigma \gamma c_{i}}\right]^{\gamma / \tilde{\gamma}}
\end{gathered}
$$

where $\tilde{\gamma} \equiv \gamma-\delta(1-\sigma)>0$ by the second-order condition. The superscript $o$ means that these quantities are the unconstrained optimal. Applying the zero profit condition to (7) yields the following equation for the investment of the firm (the total sunk cost):

$$
f^{F D I^{o}}=\frac{\gamma c_{k i}}{(\tilde{\gamma}-\gamma)}\left[\left(\frac{\omega_{i j}(a)}{M_{j i}^{\delta \rho} \alpha P_{j}}\right)^{1-\sigma} \frac{(1-\mu)(\tilde{\gamma}-\gamma) Y_{j}}{\sigma \gamma c_{k i}}\right]^{\gamma / \tilde{\gamma}}=A S_{k i j}^{o} / \sigma
$$


Equation (11) shows that the foreign capital needed to enter the market is a fraction of the affiliate sales in the foreign market. The effect of migration on FDI is clearly positive because $\frac{\partial f^{F D I^{o}}}{\partial M_{j i}}>0$.

Firms from country $i$ invest in destination $j$ as long as the profits exceed the entry cost. All firms with productivity $a \in\left[a_{L}, a_{i j}^{*}\right]$ enter the market. Hence, the least productive firm meets the following equation:

$$
f^{F D I}\left(a_{i j}^{*}\right)-f_{i j}^{H Q}\left(a_{i j}^{*}\right)=f_{i j}^{E x}
$$

The solution for the cut-off productivity is given by:

$$
a_{i j}^{*}=\left(\frac{\sigma c_{i} f_{i j}}{(\gamma / \tilde{\gamma})}\right)^{\frac{\tilde{\gamma}}{\gamma(1-\sigma)}}\left(\frac{\gamma-\tilde{\gamma}}{\sigma \gamma c_{i}}\right)^{\frac{1-\delta}{\gamma}}\left((1-\mu) Y_{j}\right)^{\frac{1}{\sigma-1}} \frac{M_{j i}^{\delta \rho} \alpha P_{j}}{\tau_{i j} c_{i}}
$$

Only a fraction $G\left(a_{k i j}^{*}\right)$ of the active firms invest in country $j$. The effect of migration on the extensive margin is also positive because $\frac{\partial a_{k i j}^{*}}{\partial M_{j i}}>0$.

\section{Migration and financial constraints}

We assume that a fraction of the investment must be borne up front. A firm from FDI source country $i$ must borrow from an external source (e.g., a bank) to invest in country $j$. Manova (2013) assumed that part of the sunk cost is invested in tangible assets and can be collateralized. In this study, however, headquarter services are intangible assets. We therefore assume that the firm borrows a fraction of its investment. As is standard in the literature, a country measure captures the degree of financial contractability $\lambda_{i} \in[0,1]$. Firms in countries with perfect contractability $\left(\lambda_{i}=1\right)$ have no financial constraints for their investment. With a probability of $1-\lambda_{i}$, the contract is not enforced and depending on their productivity, some firms will be unable to invest. 
In the standard setup, we allow firms to negotiate with banks from country $i$ or j. According to the empirical evidence, simultaneous banking crises decrease FDI (Gil-Pareja et al., 2013). We use the setup proposed by Antràs and Foley (2015) and define the sales of a liquidity constrained affiliate:

$$
\max _{p, h}\left(\Lambda_{i j}^{-d_{s}}\left(p_{i j}-M C_{i j}^{c}(a)\right) x_{i j}-f^{F D I}\right)
$$

where $\Lambda_{i j}^{-1}=\left(\lambda_{j}+\left(1-\lambda_{j}\right) \varepsilon\right)\left(\lambda_{i}+\left(1-\lambda_{i}\right) \varepsilon\right)$ is a measure of the financial instability in the pair of countries and $d_{s} \in[0,1]$ represents the fraction of the investment that is borrowed from banks. Revenues are shaved by a fraction $\varepsilon \in[0,1]$. Firms that are financially unconstrained $\left(d_{s}=0\right)$ or prefect contractability $\left(\lambda_{j}=1\right)$ are unaffected by $\Lambda_{i j}$.

In addition, we assume that banking crises interfere with the transmission of knowledge provided by migrants. In other words, migrants' contribution to reducing the marginal cost in FDI source countries with weak financial contractability or systemic banking crises is greater than in other source countries. The following expression captures this idea:

$$
M C_{i j}^{c}(a)=\omega_{i j} h_{i j}^{\delta}\left(M_{j i}\left(\frac{\Lambda_{i}}{\Lambda_{j}}\right)^{-\eta}\right)^{-\delta \rho}
$$

where $\Lambda_{i}$ and $\Lambda_{j}$ are the country measures of financial instability and $\eta \in[0,1]$ is the extent of financial information provided by migrants. When migrants provide no financial information, $\eta=0$, and expressions (14) and (6) are equivalent.

Equation (14) reveals two offsetting effects regarding the effect of financial constraints and migrants' on FDI. Firstly, financial frictions in country $i$ (FDI source country) augment the positive effect of migration on $\mathrm{FDI}^{7}$. Secondly, financial fric-

\footnotetext{
${ }^{7}$ Or from a different perspective migrants reduce the negative effect of financial constraints in
} 
tions in country $j$ (FDI host country) reduce the positive effect of migration on $\mathrm{FDI}^{8}$. These effects are higher when migrant elasticity $(\rho)$ is higher and when the degree of financial frictions are higher (for example during a banking crisis).

To gain intuition on these effects, let country $i$ be Thailand (FDI source) and country $j$ China (FDI destination). Consider now a Thai firm that needs external finance to invest in a plant in China. In the event of a systemic banking crisis in Thailand, our firm has extreme difficulties to find finance at home (country $i$ ). Casual evidence suggests that Chinese migrants living in Thailand play an active role in Thailand's investment in China (for instance through the aforementioned Bamboo network). However, the effect of Chinese migrants (e.g., providing information and contacts in China) might be lower if the financial system in China collapses.

The new headquarter services and affiliate sales of a constrained firm are derived from equations (8) and (9):

$$
\begin{aligned}
h_{i j}^{c} & =\left(\Lambda_{i j}^{-d_{s}}\left(\frac{\Lambda_{j}}{\Lambda_{i}}\right)^{(1-\sigma) \eta \delta \rho}\right)^{1 / \tilde{\gamma}} h_{i j}^{c} \\
A S_{i j}^{c} & =\left(\Lambda_{i j}^{-d_{s}}\left(\frac{\Lambda_{j}}{\Lambda_{i}}\right)^{(1-\sigma) \eta \delta \rho}\right)^{\gamma / \tilde{\gamma}} A S_{i j}^{o} .
\end{aligned}
$$

Some firms may lower the headquarter services needed for production (and hence may also lower revenues) and still enter the market. The solution for the cut-off productivity for constrained firms is given by:

$$
\bar{a}_{i j}=\Lambda_{i j}^{\frac{-d_{s}}{\sigma-1}}\left(\frac{\Lambda_{j}}{\Lambda_{i}}\right)^{-\eta \delta \rho} a_{i j}^{*}
$$

Equation (16) shows that the investment of a constrained firm is lower than that

country $i$ on FDI.

${ }^{8}$ Or from a different perspective migrants increase the negative effect of financial constraints in country $j$ on FDI. 
of an unconstrained firm because $\left(\Lambda_{i j}^{-d_{s}}\left(\frac{\Lambda_{j}}{\Lambda_{i}}\right)^{(1-\sigma) \delta \eta \rho}\right)^{\gamma / \tilde{\gamma}}<1$. Such an effect is the result of financial constraints in both countries. Financial constraints in the host country reduce the positive effect of migrants on FDI. Equation (17) shows that he effect of banking crises on the extensive margin is negative because $\Lambda_{i j}^{\frac{-d_{s}}{\sigma-1}}\left(\frac{\Lambda_{j}}{\Lambda_{i}}\right)^{-\eta \delta \rho}<$ 1 and less firms enter the market.

\section{Multiple firms}

Aggregating across firms yields the aggregate capital investment:

$$
\begin{aligned}
& F \tilde{D} I_{i j}=N_{i} \int_{a_{L}}^{\bar{a}_{i j}} \frac{A S_{i j}^{c}(a)}{\sigma} \frac{g(a)}{G\left(\bar{a}_{i j}\right)} d a= \\
= & N_{i} \frac{\gamma c_{k i}}{(\tilde{\gamma}-\gamma)}\left[\Lambda_{i j}^{-d_{s}}\left(\frac{\Lambda_{j}}{\Lambda_{i}}\right)^{(1-\sigma) \eta \delta \rho}\left(\frac{\tau_{i j} c_{i}}{M_{j i}^{\delta \rho} \alpha P_{j}}\right)^{1-\sigma} \frac{(1-\mu)(\tilde{\gamma}-\gamma) Y_{j}}{\sigma \gamma c_{i}}\right]^{\gamma / \tilde{\gamma}} \int_{a_{L}}^{\bar{a}_{i j}} a^{(1-\sigma) \gamma / \tilde{\gamma}} \frac{g(a)}{G\left(\bar{a}_{i j}\right)} d a .
\end{aligned}
$$

We can re-write equation (18) as follows:

$$
F \tilde{D} I=N_{i} \frac{A S_{i j}^{c}\left(a_{L}\right)}{\sigma} V_{i j}
$$

where

$$
V_{i j} \equiv \int_{a_{L}}^{\bar{a}_{i j}}\left(\frac{a}{a_{L}}\right)^{(1-\sigma) \gamma / \tilde{\gamma}} \frac{g(a)}{G\left(\bar{a}_{i j}\right)} d a
$$

and

$$
A S_{i j}^{c}\left(a_{L}\right)=\frac{\gamma c_{k i}}{(\tilde{\gamma}-\gamma)}\left[\Lambda_{i j}^{-d_{s}}\left(\frac{\Lambda_{j}}{\Lambda_{i}}\right)^{(1-\sigma) \eta \delta \rho}\left(\frac{\tau_{i j} c_{i} a_{L}}{M_{j i}^{\delta \rho} \alpha P_{j}}\right)^{1-\sigma} \frac{(1-\mu)(\tilde{\gamma}-\gamma) Y_{j}}{\sigma \gamma c_{i}}\right]^{\gamma / \tilde{\gamma}}
$$

Equation (20) captures the sales of the most productive firm. As stated earlier, 
we assume that $1 / a$ follows a Pareto distribution. We define $G(a)=\frac{a^{\kappa}-a_{L}^{\kappa}}{a_{H}^{\kappa}-a_{L}^{\kappa}}$, with $\kappa>(\sigma-1) \gamma / \tilde{\gamma}$. Therefore, we can re-write $V_{i j}$ as:

$$
V_{i j}=\frac{(\tilde{\gamma} / \gamma) \kappa}{(\tilde{\gamma} / \gamma) \kappa-\sigma+1} W_{i j}
$$

where

$$
W_{i j} \equiv \max \left\{\frac{\left(\frac{\bar{a}_{i j}}{a_{L}}\right)^{\kappa-(\sigma-1) \gamma / \tilde{\gamma}}-1}{\left(\frac{\bar{a}_{i j}}{a_{L}}\right)^{\kappa}-1}, 0\right\} .
$$

The selection of firms into FDI, represented by $W_{i j}$, is controlled by the cut-off variable $\bar{a}_{i j}$ in (17). Using this expression, we can obtain a log-linear and estimable equation from (19):

$$
\begin{aligned}
f d i_{i j}= & \theta_{0}+n_{i}+\frac{\gamma}{\tilde{\gamma}} y_{j}+\frac{\gamma(\sigma-1)}{\tilde{\gamma}} p_{j}-\frac{\gamma \sigma}{\tilde{\gamma}} c_{i}-\frac{\gamma(\sigma-1)}{\tilde{\gamma}} \ln \tau_{i j}+ \\
& +\frac{\gamma \rho(\sigma-1)}{\tilde{\gamma}} m_{j i}-\frac{\gamma}{\tilde{\gamma}} d_{s} \ln \Lambda_{i j}-\frac{\gamma \rho(\sigma-1) \delta \eta}{\tilde{\gamma}} \ln \frac{\Lambda_{j}}{\Lambda_{i}}+w_{i j},
\end{aligned}
$$

where lower case variables are the natural log of the upper case variables and $\theta_{0}$ is a constant that bundles the rest of parameters. Using a standard parametrization for the transfer cost yields:

$$
\frac{\gamma(\sigma-1)}{\tilde{\gamma}} \ln \tau_{i j}=\zeta d_{i j}-u_{i j}
$$

where $d_{i j}$ is the log of bilateral distance between countries and $u_{i j} \sim N\left(0, \sigma_{u}^{2}\right)$ is an unobserved i.i.d. variable representing investment frictions. By adopting standard notation, we can obtain an empirical gravity-like equation:

$$
f d i_{i j}=\theta_{0}+s_{i}+s_{j}-\zeta d_{i j}-\frac{\gamma}{\tilde{\gamma}} d_{s} \ln \Lambda_{i j}+\frac{\gamma \rho(\sigma-1) \delta}{\tilde{\gamma}}\left(m_{j i}-\eta \ln \frac{\Lambda_{j}}{\Lambda_{i}}\right)+w_{i j}+u_{i j}
$$


where $s_{i} \equiv n_{i}-\frac{\gamma \sigma}{\tilde{\gamma}} c_{i}$ and $s_{j} \equiv \frac{\gamma}{\tilde{\gamma}} y_{j}+\frac{\gamma(\sigma-1)}{\tilde{\gamma}} p_{j}$ are country fixed effects.

From equation (25), we derive three interesting predictions for empirical testing:

1. Bilateral migration from country $j$ to country $i$ increases the FDI from country $i$ to country $j$.

2. Financial frictions in country $j\left(\Lambda_{j}\right)$ reduce the positive effect of migration on FDI.

3. Financial frictions in country $i\left(\Lambda_{i}\right)$ increase the positive effect of migration on FDI.

\section{Data and empirical strategy}

\subsection{Data}

We estimate an extended gravity version of equation (25) to explain bilateral FDI from the migrant's host country to the migrant's country of origin and test the implications above. As is customary within the gravity framework, the extent of FDI flows between country pairs is directly proportional to their economic mass (i.e., GDP) and decreases with distance. The basic specification also includes other factors that affect cross-border investments. We extend this set of variables by including the number of migrants and a dummy variable that captures the existence of friction in financial markets. Table 1 describes the variables measuring these factors.

[Table 1 about here.]

We provide the descriptive statistics and correlation matrix in Table 2. The correlation of migration with the rest of variables is below 0.5 in all cases. The highest correlation is with FDI and projects. 
[Table 2 about here.]

The FDI data set is taken from the Financial Times Ltd. cross-border investment monitor (FDIMarkets, 2013). This data set covers bilateral firm-level greenfield investments from 2003 to 2012, aggregated up to the national level. Greenfield investments are optimal to measure migrant networks' influence on multinational enterprises' (MNEs') ability to procure credit. Greenfield investments imply higher plant costs and tend to suffer from credit constraints (Nocke and Yeaple, 2007; Qiu and Wang, 2011). Furthermore, the investor has no investment footprint in the host country, so migrants' impact is expected to be greater ${ }^{9}$.

We measure investment counts from FDIMarkets in firm-level projects and capital flows in constant 2005 USD. Overall, the database is heavily unbalanced, with $70 \%$ zero observations showing that not all countries received investment in all years. Table 3 displays the distribution of projects by firm size (measured by turnover). Unsurprisingly, firms are heterogeneous, and the number of investment projects carried out by firms increases with their size. Thus, smaller firms undertook, on average, 1.6 projects between 2003 and 2012, whereas bigger firms undertook an average of more than 80 in the same period. This difference reflects the differences in the headquarter services required in each case. Smaller firms are less efficient at providing headquarter services and more sensitive to changes in the economic and financial environment (Ibarra-Caton, 2015).

[Table 3 about here.]

We examine 140 host countries (migration source countries) and 12 source countries (migration destination) for which we could obtain bilateral migration data. We use information on the foreign-born population by country of birth. These data come

\footnotetext{
${ }^{9}$ Bhattacharya and Groznik (2008) found that migrant impact on FDI is much stronger for FDI than for foreign stock holdings.
} 
from the OECD International Migration Database (OECD, 2014). Table 4 lists the countries included in this study.

[Table 4 about here.]

The World Bank (2013) provides GDP measured in constant 2005 USD. Distance, common language, colony and border come from the CEPII (2011) database. These variables control for freight, information, cultural, historical and administrative transaction costs between country pairs ${ }^{10}$. We calculate an indicator for religious affinities using data from the CIA World Factbook (2011), according to the following formula for each country pair $i, j$ :

$$
\sum_{m}(\text { Share of religious group } \mathrm{m})_{i} *(\text { Share of religious group } \mathrm{m})_{j}
$$

where $m=$ Christian, Muslim, Buddhist, Hindu, Jewish.

Institutional agreements such as free trade agreements (FTA) and bilateral investment treaties (BIT) reduce uncertainty in foreign investments (Bergstrand and Egger, 2013). We construct BIT manually using data from UNCTAD (2013). FTA data come from Head et al. (2010), complemented by UNCTAD (2013) data.

One key issue is being able to identify circumstances under which the role of migrants becomes relevant. Our model assumes that alternative sources of information become even more attractive when the traditional credit channels fail. Therefore, the most common way for frictions in financial markets to appear is through systemic financial crises. Such crises imply a collapse of the country's financial markets, which forces firms to seek alternative financing sources. Similar studies (Crinò and Ogliari,

\footnotetext{
${ }^{10}$ Religious affinities increase the probability of economic transactions between nations with similar values and beliefs (Helble, 2007). This variable was introduced in the gravity equation by Helpman et al. (2008) as a control variable for religious and common law affinities between trade partners.
} 
2015; Kroszner et al., 2007; Gil-Pareja et al., 2013) have used banking crises as an exogenous negative shock to the ability of the traditional financial system to provide credit.

The data source on systemic banking crises is Laeven and Valencia (2013). These authors built a database spanning the period 1970-2011. They identified banking crises as events that simultaneously meet the following two conditions:

1. Significant signs of financial distress in the banking system (significant bank runs, losses in the banking system and/or bank liquidations)

2. Significant banking policy intervention measures in response to significant losses in the banking system ${ }^{11}$.

Our FDI data set includes total FDI from country $i$ to country $j$, but also the number of FDI projects in country $i$ targeting country $j$. Data availability allows for a richer analysis of the effect of migration and financial frictions, permitting us to disentangle the extensive margin and a sort of intensive margin of FDI.

\subsection{Empirical method}

Our baseline estimates include plain ordinary least squares (OLS), a two-stage procedure proposed by Helpman et al. (2008, HMR henceforth) and the pseudoPoisson maximum likelihood (PPML) estimator proposed by Silva and Tenreyro (2006). The OLS log version of the gravity equation incurs a self-selection bias, stemming from omitting zeros. Both HMR and PPML address this issue. HMR deals with zeros in a first probit stage, and PPML presents consistent estimates because

\footnotetext{
${ }^{11}$ These measures should include at least three of the following six: (1) deposit freezes and/or bank holidays; (2) significant bank nationalizations; (3) bank restructuring gross costs; (4) extensive liquidity support; (5) significant guarantees put in place; and (6) significant asset purchases.
} 
the estimator does not require log-linearization of the variables ${ }^{12}$. Furthermore, Silva and Tenreyro (2015) showed that HMR imposes overly strict homoscedastic restrictions on the error term, which are scarcely present in FDI or trade data. The authors showed that the simpler PPML method yields similar results to the two-step procedure.

As in HMR, we define the first stage as a probit estimation:

$$
\begin{aligned}
\varrho_{i j t}= & \operatorname{Pr}\left(T_{i j t}=1 \mid \text { Observed variables }\right) \\
= & \Phi\left(\beta \text { gravity }_{i j}+\beta_{12} B C_{i j t}+\beta_{13} \ln \left(\text { migr }_{j i t}\right)+,\right. \\
& +\beta_{14} \ln \left(\text { migr }_{j i t}\right) * B C_{i t}+\beta_{15} \ln \left(\text { migr }_{j i t}\right) * B C_{j t}+ \\
& \left.+s_{i}+s_{j}+s_{t}+\vartheta_{i j t}\right),
\end{aligned}
$$

where $T_{i j t}$ takes a value of 1 when country $i$ invests in country $j$ in year $t$ and zero if the value is zero, $\Phi($.$) is the cumulative normal standard distribution func-$ tion, and $s$ are the fixed effects for host and home countries and year. gravity $_{i j}=$ $\beta_{1} \ln \left(Y_{i t} * Y_{j t}\right)+\beta_{2} \ln \left(D_{i j}\right)+\beta_{3}$ border $_{i j}+\beta_{4}$ colony $_{i j}+\beta_{5}$ lang $_{i j}+\beta_{6}$ smctry $_{i j}+\beta_{7} r e l_{i j}+$ $\beta_{8}$ locked $_{j}+\beta_{10} B I T_{i j t}+\beta_{11} F T A_{i j t}$ captures the distance as well as other transfer cost variables described in Table (1). The term migr $_{j i t}$ is the yearly stock of migrants from country $j$ who live in country $i, B C_{i j t}$ is the number of countries that suffer systemic financial crises in year t $(0,1$ or 2$), B C_{i t}$ is a dummy set to 1 if the home country suffers a systemic financial crisis, $B C_{j t}$ is a dummy set to 1 if the host country suffers a systemic financial crisis, $\lambda_{t}$ is a fixed year effect and $e_{i j t}$ represents a stochastic error term. Coefficients $\hat{\beta}_{14}$ and $\hat{\beta}_{15}$ give a measure of the degree by which migrants transmit financial information ( $\eta$ in our model). Our model predicts that

\footnotetext{
${ }^{12}$ Moreover, it is robust to heteroscedasticity in the error term and it assures convergence of the maximum likelihood estimation by a previous inspection of the data (Silva \& Tenreyro, 2010, 2011). Additionally, Bergstrand et al. (2015) argued that the PPML estimator is appropriate for short panel gravity data.
} 
$\hat{\beta}_{14}=-\hat{\beta}_{15}$. In this specification, however, we are implicitly allowing for a different impact in host and home countries. Nonetheless, we expect that $\hat{\beta}_{14}>0$ and $\hat{\beta}_{15}<0$. The error term, which is correlated with the error term of the gravity equation, is denoted by $\vartheta_{i j t}$.

The second step runs a log-likelihood maximization estimation and includes variables that control for non-random firm selection (zeros) and firm heterogeneity ${ }^{13}$ :

$$
\begin{aligned}
\operatorname{lnFDI}_{i j t}= & \text { }_{\text {gravity }}+\beta_{12} B C_{i j t}+\beta_{13} \ln \left(\text { migr }_{j i t}\right)+ \\
& +\beta_{14} \ln \left(\text { migr }_{j i t}\right) * B C_{i t}+\beta_{15} \ln \left(\text { migr }_{j i t}\right) * B C_{j t} \\
& +s_{i}+s_{j}+s_{t}+\hat{\bar{w}}(\kappa)+\theta \hat{\bar{\vartheta}}_{i j t}+v_{i j t},
\end{aligned}
$$

where $F D I_{i j t}$ is the aggregate investment between home country $i$ and host $j$ in year $t, \hat{\bar{\vartheta}}_{i j t}^{*}=\phi\left(\hat{z}_{i j t}\right) / \Phi\left(\hat{z}_{i j t}\right)$ is the inverse Mills ratio, $\hat{z}_{i j t}^{*}=\Phi^{-1}\left(\hat{\varrho}_{i j t}\right)$. $\hat{\varrho}_{i j t}$ are the the probabilities obtained in the first probit step of equation (26), and $\phi($.$) is the$ standard normal density function ${ }^{14} \cdot \hat{\bar{w}}(\kappa)$ is defined as:

$$
\hat{\bar{w}}(\kappa)=\ln \left\{\frac{\exp \left[\kappa_{1}\left(\hat{z}_{i j t}^{*}+\hat{\bar{\vartheta}}_{i j t}^{*}\right)\right]-1}{\exp \left[\kappa_{2}\left(\hat{z}_{i j t}^{*}+\hat{\bar{\vartheta}}_{i j t}^{*}\right)\right]-1}\right\},
$$

where $\kappa_{1}$ and $\kappa_{2}$ are the parameters obtained from (22). The parameter $\hat{\bar{w}}(\kappa)$ affects both firm selection and firm heterogeneity.

\footnotetext{
${ }^{13}$ For identification, this step excludes variables that affect the probability of FDI but not FDI's volume. HMR proposes to drop religion to drop religion (for trade).

${ }^{14}$ Following HMR, some dyads are such that their probability of investment is indistinguishable from 1. The inverse Mills ratio would be undefined for predicted probabilities close to 1, therefore all probabilities $>0.9999999$ are converted to equal 0.9999999 .
} 


\section{$5 \quad$ Results and discussion}

Table 5 presents the results for the estimation of the augmented gravity equation for $T_{i j t}$ (the probability of FDI) (column 1), FDI flows (columns 2-6) and extensive margin (columns 7-10). The plain ordinary least squares (OLS) estimation for gravity equations suffers from several well-known biases. The first such bias is misspecification due to the omission of multilateral resistance terms (Anderson and Van Wincoop, 2003). The usual solution for this type of bias involves introducing country fixed effects (CFE) for both host and home countries. Nevertheless, CFE does not eliminate unobserved bilateral heterogeneity because it fails to consider variables apart from the country pair level that might affect bilateral FDI. When we add country-pair fixed effects (CPFE), we eliminate all dyadic variables with no time variation. Specifically, the CPFE comprises only GDP, BIT, FTA and migration ${ }^{15}$.

For the extensive margin we use the number of firm-level projects as the dependent variable. The incorporation of trade and FDI margins reduces the overaggregation bias of capital flows in the estimation of the gravity equation (Hillberry, 2002; Hillberry \& Hummels, 2008). The extensive margin reveals information about the creation of new partners (Felbermayr and Kohler, 2006).

There are no major differences between the two equations in terms of significance and direction of effect for most explanatory variables. A general result is that GDP is not significant in any model (except the PPML estimate). Bilateral treaties have an unexpected negative effect both on total FDI and the number of project, the same as free trade agreements, when heterogeneity is dealt with fixed country effects (the only exception being the OLS estimate in column 3). However, the inclusion of country-pair fixed effects implies both estimates turn out to have a positive impact on the number of projects. For number of projects, a positive effect appears when

\footnotetext{
${ }^{15} \mathrm{HMR}$ did not converge with CPFE.
} 
country-pair fixed effects are included in the estimation. Regarding the standard bilateral equation in the gravity equation, we observe that distance, common language and former colony relationships are significant and have the expected signs in all cases. Conversely, being part of the same country in the past or sharing a common religion never affect the dependent variables. Being a landlocked country is significant for total volume of FDI, whereas sharing a border affects only the number of FDI projects. The border effect displays positive sign in the first stage of the HMR procedure and a negative sign in the second one; however, we have already explained the drawback with this estimation method that makes us prefer the PPML procedure. All variables are dropped in the estimates with country-pair fixed effects.

\section{[Table 5 about here.]}

We observe certain heterogeneity in migrant's positive effect in FDI. This effect is greater in the PPML estimate because this method uses zeros to include information about less productive firms. Furthermore, we observe differences between FDI flows and the extensive margin. Our findings imply that migrant's effect on FDI is mainly driven by the extensive margin. In fact, once the heterogeneity has been controlled with country-pair fixed effect, migration is only positive and significant for the number of projects in column 10 (although at $10 \%$ level). These findings imply that migrants affects firms' decisions to engage in new FDI projects (extensive margin) much more than it affects total FDI flows. Finally, the non-significance of BC implies that major financial crises do not seem to influence international capital flows for the subset of countries included in the regression ${ }^{16}$.

The results herein show that migrants help to promote FDI, however these results do not show yet whether the migrant effect relates to the way financial markets operate. Therefore, we explore now whether financial frictions, which are likely to

\footnotetext{
${ }^{16}$ For empirical evidence related to the global effect of BC refer to Gil-Pareja et al. (2013).
} 
force MNE aiming to invest abroad to explore additional funding opportunities, may interact with migrants' effect on FDI. We do so by introducing an interaction term between the number of migrants and the $B C$ variable. We consider the impact of a crisis in the host country $\left(B C_{j t}\right)$ and in the home country $\left(B C_{i t}\right)$. Table 6 presents the outcomes, showing only results for variables of interest ${ }^{17}$.

[Table 6 about here.]

As observed in the baseline results, a systemic financial crisis does not per se affect the total volume of FDI, but rather the existence of FDI. Financial frictions, however, are crucial to determine the direction of the effect of migrants. Two basic asymmetries can be identified in reference to the impact of migrants when they interact with financial frictions. First, frictions in the FDI source country imply that firms must look for additional financial resources. Migrants may provide useful information in this context. Thus, in situations of financial frictions, migrants affect the probability of investment more than they do in the absence of frictions. Conversely, if the financial crisis happens in the migrants' homeland, their information is less valuable and, therefore, their impact is smaller ${ }^{18}$. Second, although migrants seemingly provide information that helps the firm to decide whether to proceed with an investment project, migrants seem not to affect the project's size. The simple answer to this question is that firm heterogeneity matters. Total FDI from one country is the sum of very different investments by heterogeneous firms. Under these circumstances, the theoretical framework developed in section 3 predicts that financial constraints have a stronger effect on less productive firms. Thus, below a certain

\footnotetext{
${ }^{17}$ The remaining estimates are available upon request.

${ }^{18}$ With regard to our preferred PPML estimates, the net effect of migrants is the sum of the migrant's estimated coefficient (0.219) and the estimated value of the interaction term (-0.041). In this case, the net effect of migrants is still positive but comparatively lower in the event of a banking crisis in their homeland. In the case of the probit estimates, the net effect of migrants is close to zero.
} 
productivity threshold, firms do not enter the foreign market. In our setup, migrants help borderline cases to cross borders. Therefore, we should expect a greater impact on small projects.

To test this last assumption's validity, we test the effects of migration across different FDI levels using quantile regression. We follow the method set forth by Paniagua et al. (2015), who developed a CPFE quantile regression procedure for gravity estimates of FDI. Table 7 shows the results of this analysis.

[Table 7 about here.]

Results in Table 7 report the quantile regression results. Focusing on the variables of interest, the results shed light on some interesting patterns that remained hidden in our previous estimates.

First, the incidence of migration is quite steady across quantiles. That is, migration has a homogeneous effect at different FDI levels. Second, systemic financial crises affect the median. In contrast, migrants in home countries $i$ with systemic financial crises positively affect only the lower FDI level, where less productive firms are expected to be. Size makes firms particularly dependent on personal contacts for their investments abroad ${ }^{19}$. Regarding the effect of financial constraints in country j, migrants have no significant effect on FDI. Finally, as in Paniagua et al. (2015), the quantile estimates of FTA and BIT are more in line with economic intuition than previous estimates. We also observe a negative incidence of the variable banking crises around the median. Firms at the upper and lower tails are resilient to financial constraints. Figure 1 illustrates these effects.

[Figure 1 about here.]

\footnotetext{
${ }^{19}$ This evidence is consistent with findings reported by Murat and Pistoressi (2009) regarding the prominent role of migrant networks in countries such as Italy with a large number of small and medium-sized enterprises. A similar idea was highlighted by Eckstein (2013).
} 
The graphs in Figure 1 show how the estimated coefficients vary across quantiles. The interaction between migrants and BC (in the last two boxes) decreases in the upper tail. Migrants' financial brokerage is therefore more evident in country pairs with smaller or fewer project flows between them. Additionally, quantile regressions solve some puzzling issues like BIT's persistent negative coefficient or the non-significant impact of BC in OLS and PPML, since these two estimation methods capture mean effects.

\section{Conclusions}

Improving the knowledge of the interplay among migration, FDI and financial constraints is essential to understanding the way globalization affects modern economies. The increasing importance of foreign workers - whether employees or entrepreneurs - in the labour market has recently raised questions about their influence on foreign investment. Empirical literature suggests that migrants normally have knowledge and experience about their home markets and can provide valuable information that would otherwise be difficult to obtain.

This paper provides new insights into the impact of migrants on their homeland. The paper is devoted to analysing a specific channel through which migrants may affect FDI, namely their influence in reducing information costs associated with headquarter services. By reducing the costs of transferring information between headquarter and affiliates, migrants promote both FDI flows and foreign projects in their country of origin. We assume that part of the information transmitted by

migrants relates to their home financial system. This type of knowledge may be particularly relevant during banking crisis or periods of financial distress.

Our findings show that migrant networks are likely to reduce the effect of finan- 
cial constraints faced by foreign firms. This effect is more pronounced among new investment projects whose approval would otherwise be unlikely. Nevertheless, our results show that migrants' ability to broaden financial alternatives available to foreign firms is mediated by two factors: first, by financial constraints in the migrant's country of origin, and second, by FDI level. Migrants have a greater effect on small projects, which may be more sensitive to financial constraints than large projects are.

In summary, in addition to reporting on the role of migrants in overcoming information barriers and enforcing contracts across national boundaries, this paper provides insights into a new mechanism that may reinforce the migration-FDI link. Specifically, results highlight a business gain associated with the role of migrants as suppliers of financial information when MNEs cannot secure financing at home. Our findings imply that migrants can contribute to a higher integration of their home countries within the global economy through greater FDI presence. We thereby provide evidence supporting the argument that migrants play a relevant and positive role in their home economies. These findings contribute to bringing the positive effects of migration to the forefront of policymakers' decision-making processes.

The main novelty of this paper has been to provide new insights into the effect of financial crisis on the migration-FDI link without accounting by migrant's heterogeneity. An interesting avenue for future research would be to focus on how the migration-FDI link can be affected by both the educational attainment of migrants as well as their occupation level. 


\section{Acknowledgements}

The authors gratefully acknowledge financial support from the Ministerio de Economía y Competitividad (ECO2011-27619; ECO2014-58975-P; ECO2015-68057-R), Pla de Promoció de la Investigació, Universitat Jaume I (P1.1B2013-22) and from the Catholic University of Valencia (PRUCV/2015/652).

They are also indebted to valuable comments from an anonymous referee as well as Frederic Docquier, Amandine Aubry, Farid Toubal and the participants at the 4th Meeting of International Economics organized by the Instituto de Economía Internacional (Universitat Jaume I of Castellón, September 2015).

\section{References}

Alba, J.D., P. Wang and W. Ho, 2007. Relative Access to Credit, Relative Wealth and FDI: Firm-Level Evidence from Japanese FDI into the United States. Journal of Economic Integration, 22(2), 231-255.

Alfaro, L., Chanda, A. Kalemli-Ozcan, S. and Sayek, S. (2004). FDI and Economic Growth: the Role of Local Financial Markets. Journal of International Economics 64, 89-112.

Anderson, J. and Van Wincoop, E. 2003. Gravity with Gravitas: A Solution to the Border Puzzle, American Economic Review, 93(1), 170-192.

Antràs, P., and Foley, C. F. (2015). Poultry in Motion: A Study of International Trade Finance Practices. Journal of Political Economy, 123(4), 853-901.

Antràs, P., and Helpman, E. (2004). Global Sourcing. Journal of Political Economy, $112(3), 552-580$.

Aubry, A. , Kugler, M. and Rapoport, H. (2014). Migration, FDI and the Margins of Trade. Mimeo.

Bandelj, N. (2002). Embedded Economies: Social Relations as Determinants of Foreign Direct Investment in Central and Eastern Europe. Social Forces 81(2), 411-444.

Bergstrand, J. H., and Egger, P. (2013). What Determines BITs? Journal of International Economics, 90(1), 107-122. 
Bergstrand, J. H., Egger, P., and Larch, M. (2008). The New Expats: Economic Determinants of Bilateral Expatriate, FDI, and International Trade Flows. University of Notre Dame working paper.

Bergstrand, J. H., Larch, M., \& Yotov, Y. V. (2015). Economic integration agreements, border effects, and distance elasticities in the gravity equation. European Economic Review, 78, 307-327.

Bhattacharya, U. and Groznik, P. (2008). Melting Pot or Salad Bowl: Some Evidence from US Investment Abroad. Journal of Financial Markets 11(3), 228-258.

Blalock, G., P.J. Gertler and D.I.Levine, 2008. Financial Constraints on Investment in an Emerging Market Crisis, Journal of Monetary Economics, 55, 568-591.

Buch, C.M., I. Kesternich, A. Lipponer and M. Schinitzer, 2014. "Financial Constraints and Foreign Direct Investment: Firm-Level Evidence", Review of World Economics 150(2), 393-420.

Buch, C., Kleinert, J. and Toubal, F. (2006). Where enterprises lead, people follow? Links between migration and FDI in Germany. European Economic Review 50, 2017-2036.

Campello, M., J.R. Graham and C.R. Harvey, 2010. The Real Effects of Financial Constraints: Evidence from a Financial Crisis. Journal of Financial Economics, 97, 470-487.

CEPII. (2011). Centre d'études prospectives et d'informations internationales. Retrieved from http://www.cepii.fr

Chen, M. (2004). Asian Management Systems: Chinese, Japanese and Korean Styles of Business. Singapore: Thomson Learning.

CIA World Factbook (2011). Retrieved from https://www.cia.gov/library/publications/theworld-factbook.

Crinò, R., and Ogliari, L. (2015). Financial Frictions, Product Quality, and International Trade. Mimeo.

Cristea, A.D. (2015) The effects of communication costs on trade in headquarter services, Review of World Economics, 151 (2), 255-289.

Daude, C. and Fratzscher, M. (2008). The pecking order of cross-border investment. Journal of International Economics 74, 94-119.

Davis, J.C. and J.V. Henderson (2008) The agglomeration of headquarters, Regional Science and Urban Economics, 38 (5), 445-460.

Davies, R.B. (2005) Fragmentation of headquarter services and FDI, The North American Journal of Economics and Finance, 16 (1), 61-79.

Di Giovanni, J. (2005). What Drives Capital Flows? The Case of Cross-Border Activity and Financial Deeping. Journal of International Economics 65, 127-149. 
Docquier, F. and Lodigiani, E. (2010). Skilled Migration and Business Network. Open Economies Review 21, 565-588.

Eckstein, S. (2013). Immigrants from Developing Countries. An Overview of their Homeland Impacts. In Eckstein, S. and Najam, A. (eds). How Immigrants Impact their Homelands. Duke University Press.

FDIMarkets. (2013). FDI Markets - The Financial Times Ltd. Retrieved from http://www.fdimarkets.com

Felbermayr, G. J., and Kohler, W. (2006). Exploring the intensive and extensive margins of world trade. Review of World Economics, 142(4), 642-674.

Flisi, S. and Murat, M. (2011). The Hub Continent. Immigrant networks, Emigrant Diasporas and FDI. The Journal of Socio-Economics 40, 796-805.

Foad, H. (2012). FDI and Immigration: a Regional Analysis. The Annals of Regional Science 49, pp. 237-259.

Foley, C. and Kerr, R. (2013). Ethnic Innovation and US Multinational Firm Activity. Management Science 59 (7), 1529-1544.

Gao, T. (2003). Ethnic Chinese Networks and International Investment: Evidence from Inward FDI in China. Journal of Asian Economies 14, 611-629.

Gheasi, M. Nijkamp, P. and Rietveld, P. (2013). Migration and Foreign Direct Investment: Education Matters. The Annals of Regional Science, 51 (1), 73-87.

Gil-Pareja, S., Llorca, R. and Paniagua, J. (2013). The Effect of the Great Recession on Foreign Direct Investment: Global Empirical Evidence with a Gravity Approach. Applied Economic Letters 20 (13), 1244-1248.

Gould, D. (1994). Immigrant Links to the Home Country: Empirical Implications for U.S. Bilateral Trade Flows. The Review of Economics and Statistics 76 (2): 302-316.

Head, K., Mayer, T., and Ries, J. (2010). The erosion of colonial trade linkages after independence. Journal of International Economics, 81, 1-14.

Helble, M. (2007). Is God good for trade? Kyklos, 60(3), 385-413.

Helpman, E. (1984). A simple theory of international trade with multinational corporations. Journal of Political Economy, 451-471.

Helpman, E., Melitz, M., \& Rubinstein, Y. (2008). Estimating Trade Flows: Trading Partners and Trading Volumes. The Quarterly Journal of Economics, 441-487.

Helpman, E., Melitz, M., and Yeaple, S. R. (2004). Export versus FDI with heterogeneous firms. American Economic Review, 94(1), 300-316.

Henderson, J.V. and Y. Ono (2008) Where do manufacturing firms locate their headquarters? Journal of Urban Economics, 63 (2), 431-450. 
Héricourt, J. and Poncet, S. (2009). FDI and Credit Constraints: Firm-Level Evidence from China. Economic System 33, 1-21.

Hillberry, R. (2002). Aggregation bias, compositional change, and the border effect. Canadian Journal of Economics, 35(3), 517-530.

Hillberry, R., and Hummels, D. (2008). Trade responses to geographic frictions: A decomposition using micro-data. European Economic Review, 52(3), 527-550.

Ibarra-Caton, M. (2015). Headquarter Services in the Global Integration of Production. Mimeo.

Ivlevs, A. and De Melo, J. (2010). FDI, the Brain Drain and Trade: Channels and Evidence. Annals of Economics and Statistics/Annales d'Économie et de Statistique, 103-121.

Javorcik, B., Ozden, C., Spatareanu, M. and Neagu, C. (2011). Migrant networks and foreign direct investment. Journal of Development Economics 94, 231-241.

Kleinert, J., and Toubal, F. (2010). Gravity for FDI. Review of International Economics, $18(1), 1-13$.

Kroszner, R.S., L. Laeven and D. Klingebiel, (2007). Banking Crises, Financial Dependence, and Growth, Journal of Financial Economics, 84 (1), 187-228.

Kugler, M. and Rapoport, H. (2007). International labor and capital flows: complements or substitutes? Economics Letters 94, 155-162.

Laeven, L., and Valencia, F. (2013). Systemic Banking Crises Database. IMF Economic Review, 61(2), 225-270.

Lovely, M.E., S.S. Rosenthal and S. Sharma (2005) Information, agglomeration and the headquarters of U.S. exporters, Regional Science and Urban Economics, 35 (2), 167-191.

Manova, K. (2013). Credit Constraints, Heterogeneous Firms,and International Trade. The Review of Economic Studies 80, pp.711-744

Melitz, M. (2003). The Impact of Trade on Intra-Industry Reallocations and Aggregate Industry Productivity. Econometrica 71 (6), pp. 1695-1725

Murat, M. and Pistoresi, B. (2009). Emigrant and immigrant networks in FDI. Applied Economics Letters 16, 1261-1264.

Nocke, V., and Yeaple, S. R. (2007). Cross-border mergers and acquisitions vs. Greenfield foreign direct investment: The role of firm heterogeneity. Journal of International Economics, 72(2), 336-365.

OECD (2014). International Migration Database (http://stats.oecd.org)

Paniagua, J. (2015). A gravity model for foreign re-investment. Economics Bulletin, 35(1), 627-632. 
Paniagua, J. and Sapena, J. (2013). The Ethics of Foreign Knowledge Brokers: a Conceptual and Empirical Framework. European Journal of International Management 7 (3), 333-349.

Paniagua, J., Figueiredo, E., and Sapena, J. (2015). Quantile regression for the FDI gravity equation. Journal of Business Research, 68(7), 1512-1518.

Qiu, L. D., and Wang, S. (2011). FDI Policy, Greenfield Investment and Cross-border Mergers. Review of International Economics, 19(5), 836-851.

Rajan, R. G., \& Zingales, L. (1998). Financial dependence and growth. The American Economic Review, 88(3), 559.

Rueda-Armengot, C. and Peris-Ortiz, M. (2012). The Emigrant Entrepreneur: a Theoretical Framework and Empirical Approximation. International Entrepreneurship and Management Journal 8 (1), 99-118.

Saxenian, S. (2002). Transnational Communities and the Evolution of Global Production Networks: The Cases of Taiwan, China and India. Industry and Innovation 9 (3), 183-202.

Silva, J.M.C.S., and Tenreyro, S. (2006). The log of gravity. The Review of Economics and Statistics, 88(4), 641-658.

Silva, J.M.C.S., and Tenreyro, S. (2010). On the Existence of the Maximum Likelihood Estimates in Poisson Regression. Economics Letters, 10(2), 310-312.

Silva, J.M.C.S., and Tenreyro, S. (2011). Poisson: Some convergence issues. Stata Journal, 11(2), 207-212.

Silva, J.M.C.S., \& Tenreyro, S. (2015). Trading partners and trading volumes: implementing the Helpman-Melitz-Rubinstein model empirically. Oxford Bulletin of Economics and Statistics, 77(1), 93-105.

Strauss-Kahn, V. and X. Vives (2009) Why and where do headquarters move?, Regional Science and Urban Economics, 39 (2), 168-186.

Tong, S. (2005). Ethnic Networks in FDI and the Impact of Institutional Development. Review of Development Economics 9 (4), 563-580.

UNCTAD. (2013). United Nations Conference on Trade and Development. Retrieved from www.unctad.org

Weidenbaum, M. and Hughes, S. (1996) The Bamboo Network. New York: Free Press

World Bank. (2013). World Bank Open Data. Retrieved from www.worldbank.org 
Table 1: Standard gravity variables Gravity variables without time variation

\begin{tabular}{|c|c|}
\hline \multicolumn{2}{|r|}{ Gravity variables without time variation } \\
\hline $\ln \left(D_{i j}\right)$ & Logarithm of the distance in kilometres between country capitals \\
\hline border $_{i j}$ & $\begin{array}{l}\text { Dummy variable that takes the value } 1 \text { when countries share a } \\
\text { common border, and } 0 \text { otherwise }\end{array}$ \\
\hline $\operatorname{col}_{i j}$ & $\begin{array}{l}\text { Dummy variable that takes the value } 1 \text { if the two countries have } \\
\text { ever had a colonial link, and } 0 \text { otherwise }\end{array}$ \\
\hline $\operatorname{lang}_{i j}$ & $\begin{array}{l}\text { Dummy variable that takes the value } 1 \text { if both countries share the } \\
\text { same official language }\end{array}$ \\
\hline$r e l_{i j}$ & $\begin{array}{l}\text { Composite index that measures the religious affinity between } \\
\text { country pairs, with values ranging from } 0 \text { to } 1\end{array}$ \\
\hline smctry $_{i j}$ & $\begin{array}{l}\text { Dummy variable that indicates if both countries were part of the } \\
\text { same country in the past }\end{array}$ \\
\hline locked $_{i j}$ & Variable equal to 1 if a country is landlocked \\
\hline \multicolumn{2}{|r|}{ Gravity variables with time variation } \\
\hline $\ln \left(Y_{i t} * Y_{j t}\right)$ & Logarithm of GDP in constant 2005 USD. \\
\hline$F T A_{i j t}$ & $\begin{array}{l}\text { Dummy variable that takes a value of one when both countries } \\
\text { have a free trade agreement in force }\end{array}$ \\
\hline$B I T_{i j t}$ & $\begin{array}{l}\text { Dummy variable that takes a value of one if the country pair has a } \\
\text { bilateral investment treaty in force }\end{array}$ \\
\hline
\end{tabular}




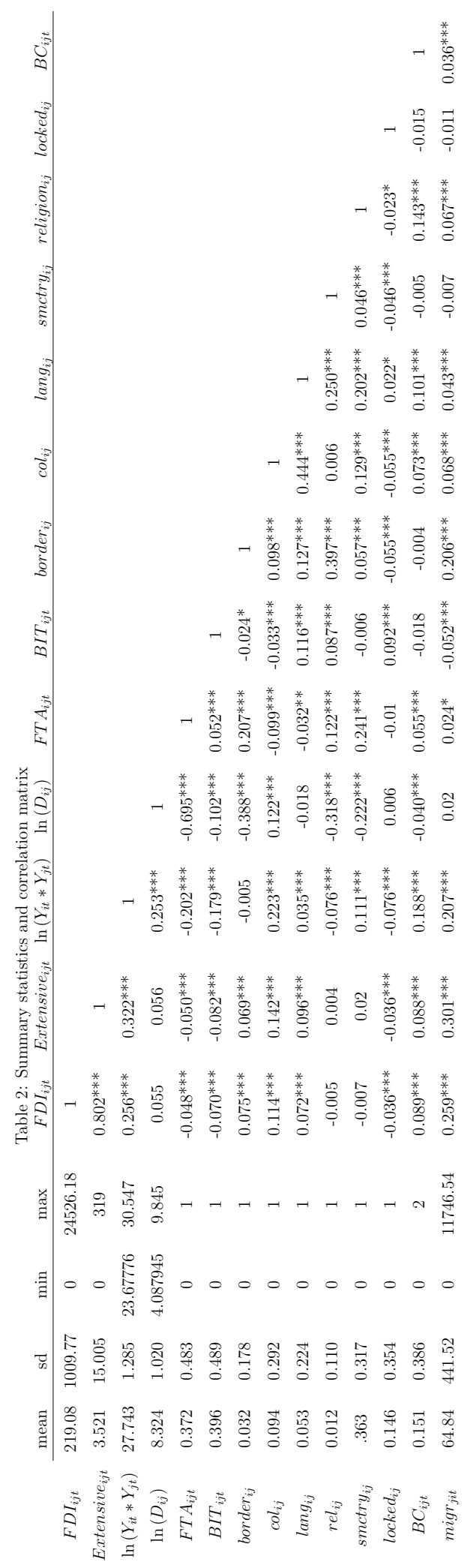


Table 3: Foreign projects by parent company turnover

\begin{tabular}{cccc}
\hline Turnover (mUSD) & Parent companies (HQ) & Projects & HQ/projects \\
\hline $0-5$ & 632 & 1031 & 1.63 \\
$5-50$ & 869 & 2631 & 3.03 \\
$50-500$ & 843 & 3586 & 4.25 \\
$500-5000$ & 828 & 7149 & 8.63 \\
$5000-50,000$ & 1301 & 19525 & 15.01 \\
$50,000+$ & 128 & 10298 & 80.45 \\
\hline
\end{tabular}


Table 4: List of Countries FDI Home (migration destination)

Australia, Austria, Denmark, Spain, Finland, Hungary, Iceland, Israel, Netherlands, Norway, Sweden, United States.

\begin{tabular}{l}
\hline FDI Host (migration source) \\
Afghanistan, Albania, Algeria, Angola, Argentina, Armenia, \\
Australia, Austria, Azerbaijan, Bahamas, Bahrain, Bangladesh, \\
Belarus, Belgium, Bermuda, Bolivia, Bosnia-Herzegovina, \\
Botswana, Brazil, Bulgaria, Burkina Faso, Cambodia, Cameroon, \\
Canada, Cape Verde, Chile, China, Colombia, Costa Rica, Cote \\
d'Ivoire, Croatia, Cuba, Cyprus, Czech Republic, Denmark, \\
Dominican Republic, Ecuador, Egypt, El Salvador, Equatorial \\
Guinea, Estonia, Ethiopia, Fiji, Finland, France, Georgia, \\
Germany, Ghana, Greece, Guatemala, Guinea, Haiti, Honduras, \\
Hong Kong, Hungary, Iceland, India, Indonesia, Iran, Iraq, \\
Ireland, Israel, Italy, Jamaica, Japan, Jordan, Kazakhstan, Kenya, \\
Kuwait, Laos, Latvia, Lebanon, Liberia, Libya, Lithuania, \\
Luxembourg, Macau, Macedonia FYR, Malawi, Malaysia, Mali, \\
Malta, Mauritania, Mexico, Moldova, Mongolia, Montenegro, \\
Morocco, Mozambique, Namibia, Nepal, Netherlands, New \\
Zealand, Nicaragua, Nigeria, Norway, Oman, Pakistan, Panama, \\
Papua New Guinea, Paraguay, Peru, Philippines, Poland, \\
Portugal, Qatar, Romania, Russia, Rwanda, Saint Vincent, Saudi \\
Arabia, Senegal, Serbia, Sierra Leone, Singapore, Slovakia, \\
Slovenia, Somalia, South Africa, South Korea, Spain, Sri Lanka, \\
Sudan, Sweden, Switzerland, Syria, Thailand, Trinidad and \\
Tobago, Tunisia, Turkey, Turkmenistan, Uganda, UK, Ukraine, \\
United Arab Emirates, United States, Uruguay, Uzbekistan, \\
Venezuela, Vietnam, Zimbabwe. \\
\hline
\end{tabular}




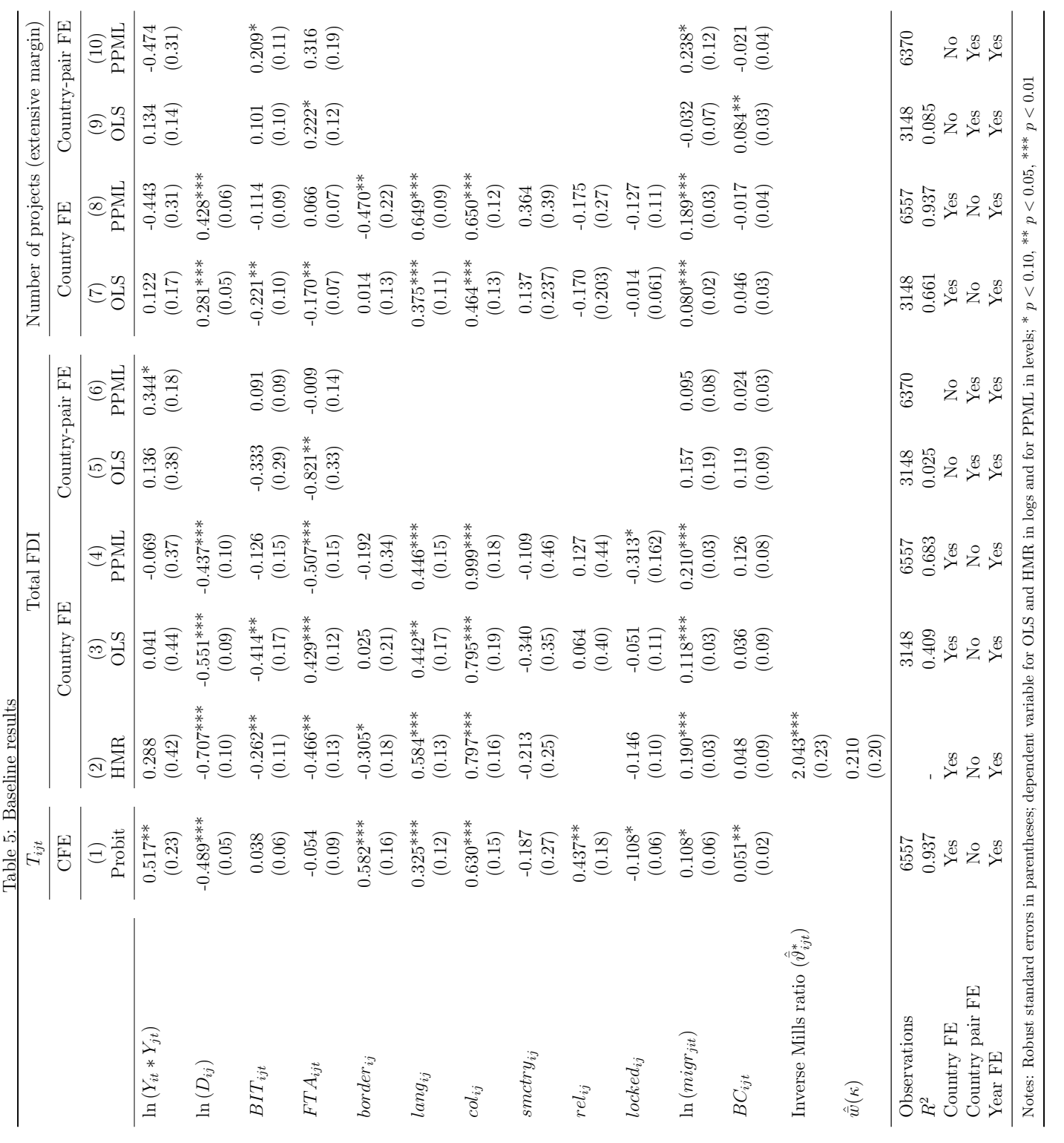




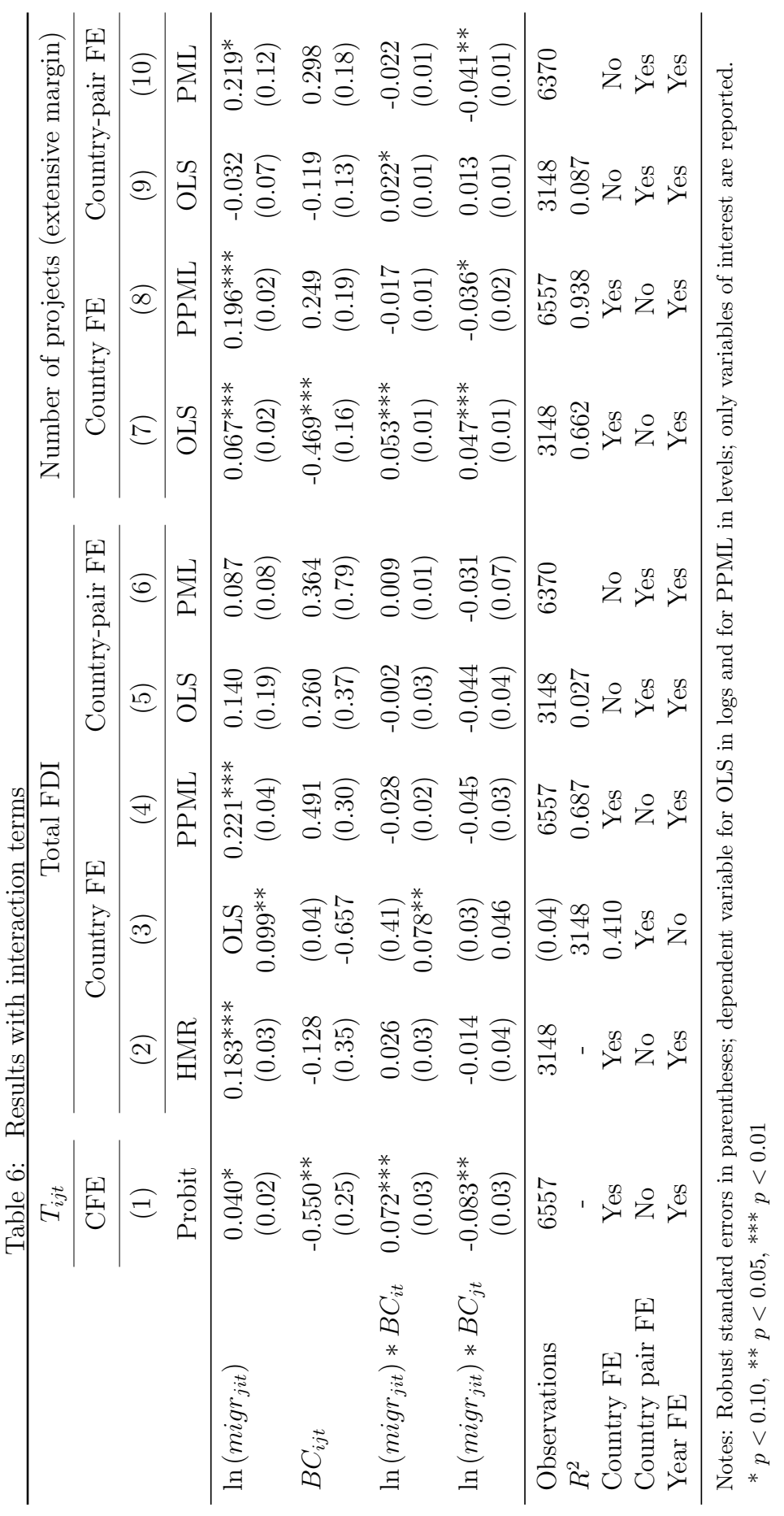


Table 7: Quantile Regression Results

\begin{tabular}{lcccc}
\hline & $(1)$ & $(2)$ & $(3)$ & $(4)$ \\
\cline { 2 - 5 } & $\mathrm{Q}(0.25)$ & $\mathrm{Q}(0.50)$ & $\mathrm{Q}(0.75)$ & $\mathrm{Q}(0.90)$ \\
\hline $\ln \left(Y_{i t} * Y_{j t}\right)$ & $0.333^{* * *}$ & $0.321^{* * *}$ & $0.288^{* * *}$ & $0.261^{* * *}$ \\
& $(0.02)$ & $(0.01)$ & $(0.02)$ & $(0.04)$ \\
$B I T_{i j t}$ & $-0.134^{*}$ & -0.0107 & -0.0116 & -0.106 \\
& $(0.07)$ & $(0.02)$ & $(0.08)$ & $(0.068)$ \\
$F T A_{i j t}$ & $0.313^{* * *}$ & $0.254^{* * *}$ & $0.230^{* * *}$ & 0.139 \\
& $(0.09)$ & $(0.03)$ & $(0.07)$ & $(0.10)$ \\
$B C_{i j t}$ & -0.373 & $-0.387^{*}$ & -0.0591 & 0.348 \\
& $(0.32)$ & $(0.21)$ & $(0.22)$ & $(0.58)$ \\
$\ln \left(\right.$ migr $\left._{j i t}\right)$ & $0.213^{* * *}$ & $0.195^{* * *}$ & $0.211^{* * *}$ & $0.180^{* * *}$ \\
$\ln \left(\right.$ migr $\left._{\text {jit }}\right) * B C_{i t}$ & $(0.01)$ & $(0.01)$ & $(0.01)$ & $(0.01)$ \\
& $0.0737^{* *}$ & $0.062^{* * *}$ & 0.029 & -0.007 \\
$\ln \left(\right.$ migr $\left._{j i t}\right) * B C_{j t}$ & $(0.02)$ & $(0.02)$ & $(0.02)$ & $(0.05)$ \\
& 0.025 & 0.033 & 0.002 & -0.034 \\
Observations $_{\text {Country pair FE }}$ & $(0.03)$ & $(0.02)$ & $(0.03)$ & $(0.05)$ \\
\hline Year FE & 3148 & 3148 & 3148 & 3148 \\
\hline
\end{tabular}

Notes: Bootstrap standard errors in parentheses.

Dependent variable total FDI in logs

${ }^{*} p<0.10,{ }^{* *} p<0.05,{ }^{* * *} p<0.01$ 
Figure 1: Quantile graphs
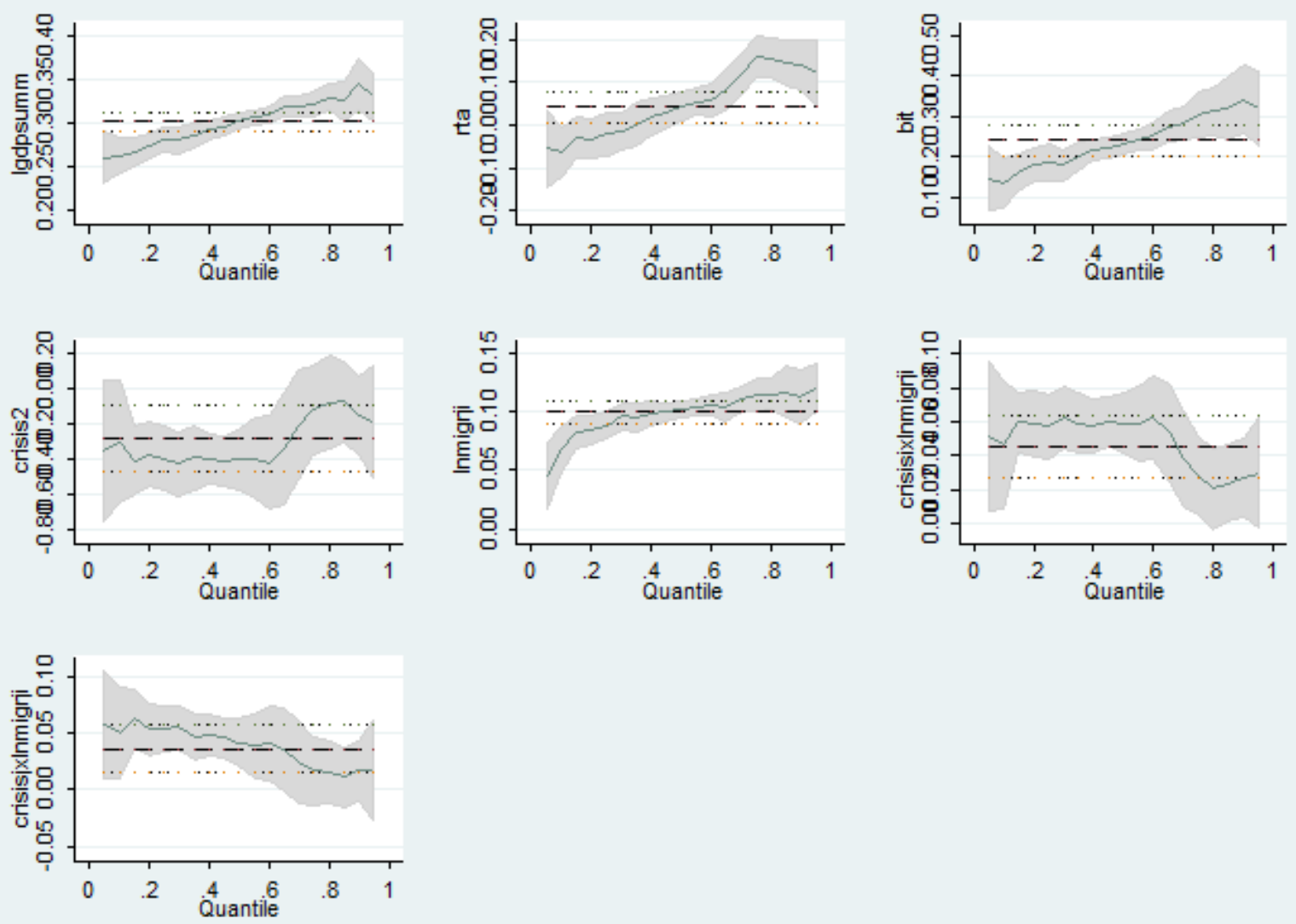